\title{
6 A Brief History of Microwave Weed Control Research
}

\subsection{Introduction}

Interest in the effects of high frequency electromagnetic waves on biological materials dates back to the late 19th century (Ark \& Parry, 1940), while interest in the effect of high frequency waves on plant material began in the 1920s (Ark \& Parry, 1940). Many of the earlier experiments on plant material focused on the effect of radio frequencies (RFs) on seeds (Ark \& Parry, 1940). In many cases, short exposure resulted in increased germination and vigour of the emerging seedlings (Nelson, Ballard, Stetson, \& Buchwald, 1976; Nelson \& Stetson, 1985; Tran, 1979); however, long exposure usually resulted in seed death (Ark \& Parry, 1940; Bebawi et al., 2007; Brodie et al., 2009).

Davis et al. $(1971 ; 1973)$ were among the first to study the lethal effect of microwave heating on seeds. They developed a set of prototypes, called "Zappers", which they tested in the field for their Company and federal and state researchers. Their final prototype, designated Zapper III, underwent tests underwent tests to provide the data necessary for the construction of the first semi-commercial prototype. In October 1971, the Company purchased all proprietary rights to a discovery made at Texas A\&M University concerning the toxic effects of microwaves on plants Davis et al. (1971; 1973).

\subsection{Pioneering Work}

The discovery was the result of the efforts by Drs Merkle, Wayland, and Davis, who were originally professors in the Soil and Crop Sciences, Physics, and Range Science Departments, respectively, of Texas A\&M University. The Company's first field prototype was named Zapper I. Zapper I was used in a cooperative testing program with US federal and state agricultural research agencies and with growers in Texas, California, Florida, New Mexico, Washington, Idaho, Nebraska, Arkansas, North Carolina, Georgia and Michigan. The Zapper I test program proved that microwaves could safely treat soil and be an effective herbicide. In addition, microwaves also proved to be toxic to nematodes, certain fungi, and to soil-borne insect pests. Further, the phenomenon of growth stimulation was first observed in plants which germinated in treated soil (Davis, 1974).

Following the initial Zapper I program, the Company built a second prototype, the Zapper III (Figure 6.1), which was used to determine the cost of Zapper treatments required to destroy various types of weed seeds under different soil conditions. The Zapper III program also experimented with different equipment configurations to determine the most efficient system design for commercial use (Davis, 1974). Both systems operated at a frequency of $2.45 \mathrm{GHz}$. 


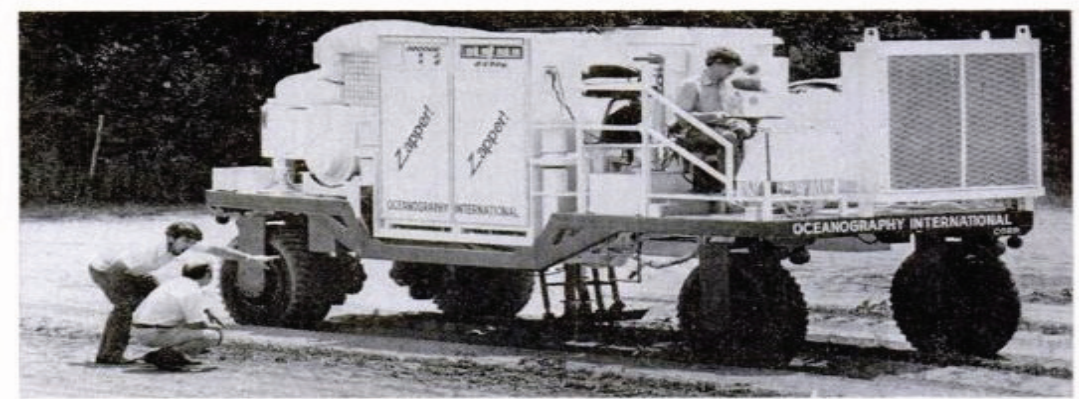

Zapper III zaps weed and soil pests by ter. Developed by Oceanography Interdischarging high-powered microwaves national Corp.. Zapper can increase crop into the ground via a sled-shaped emit- yields without the risk of pesticide use.

Figure 6.1: The Zapper III microwave prototype during field trials (Source: Anonymous, 1975).

A meta-study of published data (Menges \& Wayland, 1974; Wayland, Merkle, Davis, Menges, \& Robinson, 1975) reveals that microwave treatment of emerged weed plants, of eleven species, can be described by equations of the form (Figure 6.2):

$$
\mathrm{S}=\mathrm{a} \bullet \operatorname{erfc}[\mathrm{b}(\Psi-\mathrm{c})]
$$

When the weed species are separated into categories of broad leafed and grasses, it appears that grasses require slightly more microwave energy to achieve treatment efficacy, compared with broad leafed plants (Figure 6.3).

It also became apparent that microwave treatment of the soil could inactivate weed seeds at various depths (Menges \& Wayland, 1974; Wayland et al., 1975). The efficacy of the treatment depended on the soil type, the seed burial depth, the microwave treatment energy density and whether the soil had been irrigated prior to treatment (Figure 6.4). Irrigation prior to treatment resulted in shallower microwave heating; therefore, seed which were buried deeper in the soil profile were less affected by the microwave heating (Menges \& Wayland, 1974; Wayland et al., 1975). The consensus from this data is that $300-500 \mathrm{~J} \mathrm{~cm}^{-2}$ of microwave energy density at the soil surface, can control weeds and their seeds in the top $4-6 \mathrm{~cm}$ of soil. This is equivalent to between 30 and $50 \mathrm{GJ} \mathrm{ha}^{-1}$ of microwave energy, making microwave treatment a little more energy expensive than steam treatment (see Chapter 4).

It is unclear, from the available literature, why this promising technology did not become more widely available as a commercial system. It is apparent that the ideas generated by this early work interest persisted into the 1990's, because Nelson (1996) used a theoretical argument to dismiss microwave soil treatment as a viable prospect for weed management. The high energy input required to achieve good weed and seed control was certainly a strong argument against the adoption of this technology. 


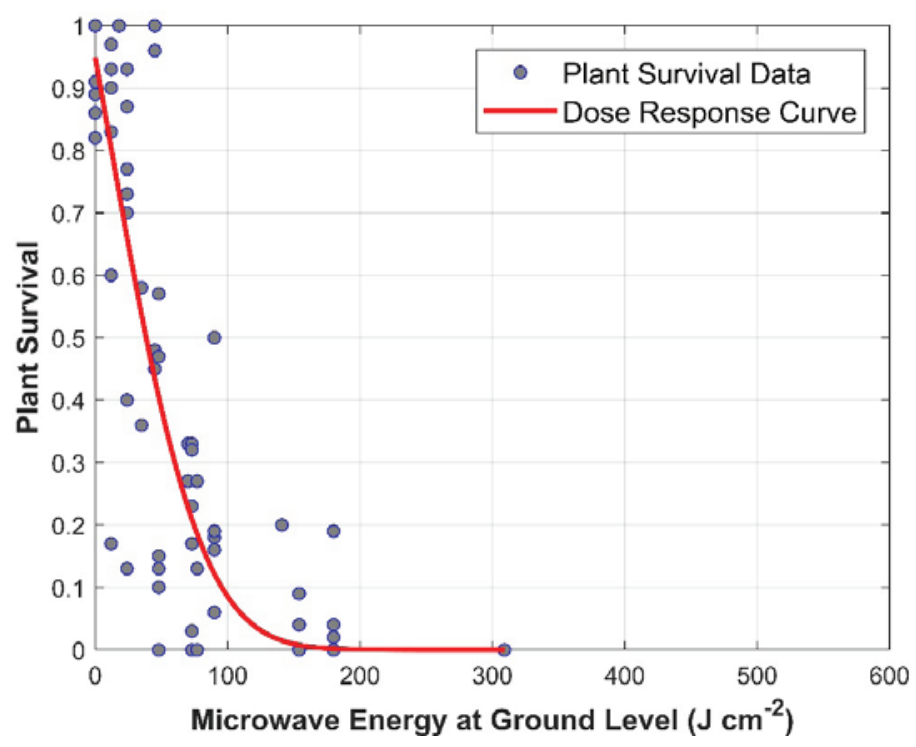

Figure 6.2: Response of 11 species of weed to microwave energy (Sources: Menges \& Wayland, 1974; Wayland et al., 1975).

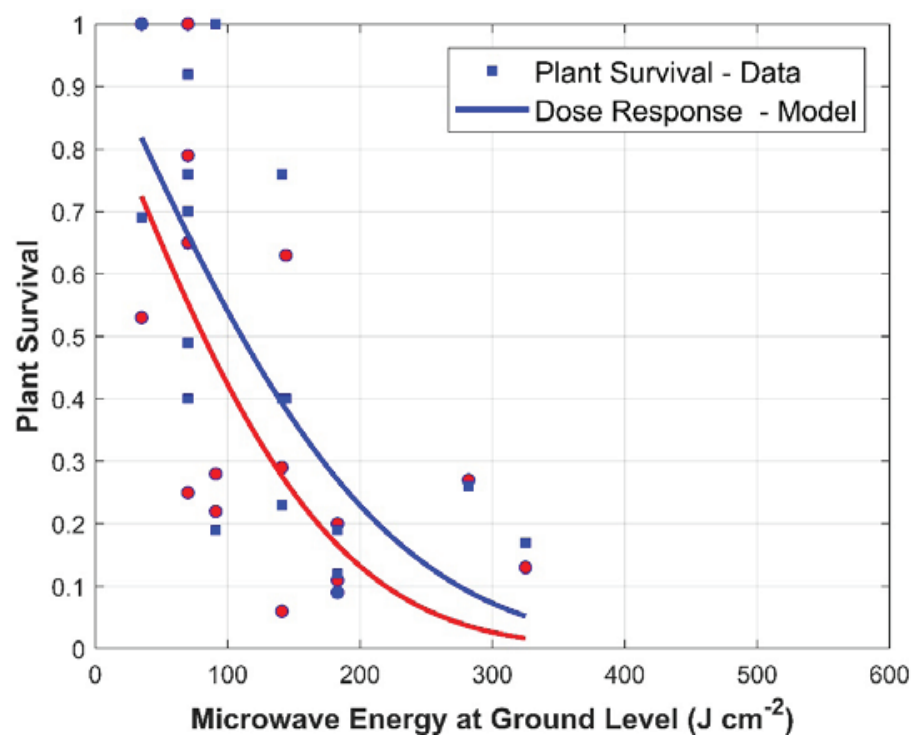

Figure 6.3: Response of grasses (blue) and broad-leafed weeds (red) to microwave energy (Sources: Menges \& Wayland, 1974; Wayland et al., 1975). 


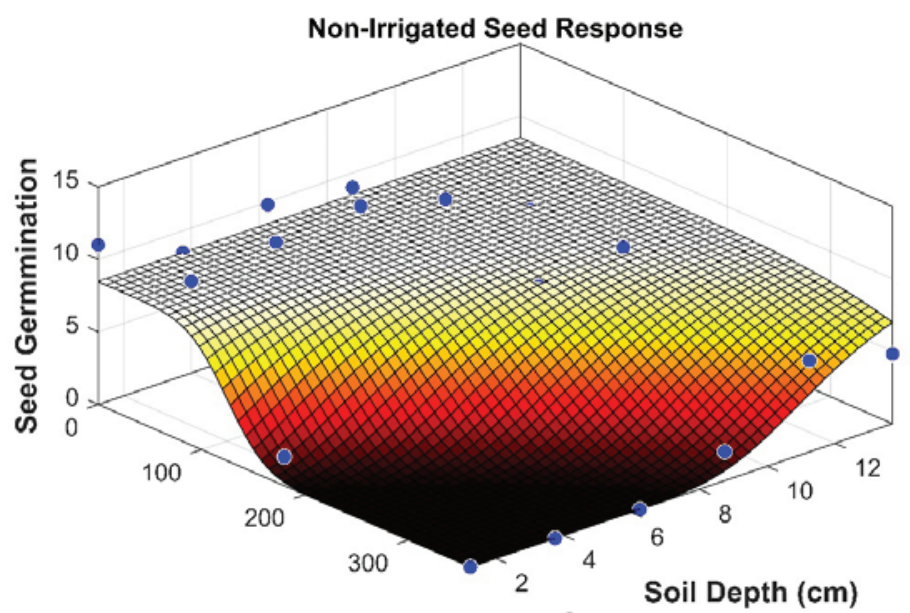

Microwave Energy at Ground Level $\left(\mathrm{J} \mathrm{cm}^{-2}\right)$

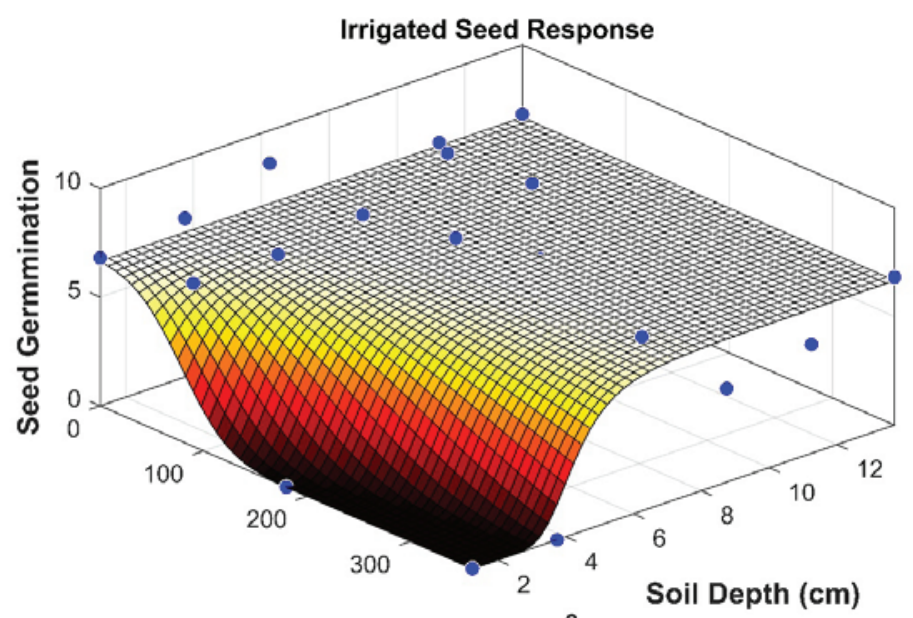

Microwave Energy at Ground Level $\left(\mathrm{J} \mathrm{cm}^{-2}\right)$

Figure 6.4: Response weed seeds in the soil to microwave energy, as a function of applied energy density, burial depth and irrigation status (Sources: Menges \& Wayland, 1974; Wayland et al., 1975).

Despite this, then there has been ongoing research interest in microwave soil treatment and weed management. Table 6.1 lists a subset of the papers that have been published on these and related topics. The consensus from these studies is that: microwave treatment can kill plants; moderate microwave treatment can break dormancy in some hard-seeded species; and high energy microwave treatment can kill seeds in the soil. 
Table 6.1: Literature addressing the application of microwave technology to seed and weed treatment.

\begin{tabular}{|c|c|}
\hline Paper Title & Reference \\
\hline $\begin{array}{l}\text { Douglas- fir tree seed germination enhancement using microwave } \\
\text { energy }\end{array}$ & (Jolly \& Tate, 1971) \\
\hline Microwave processing of tree seeds & (Kashyap \& Lewis, 1974) \\
\hline $\begin{array}{l}\text { Increasing legume seed-germination by VHF and microwave dielectric } \\
\text { heating }\end{array}$ & (Nelson et al., 1976) \\
\hline $\begin{array}{l}\text { Effects of low-level microwave radiation on germination and growth rate } \\
\text { in corn seeds }\end{array}$ & $\begin{array}{l}\text { (Bigu-Del-Blanco, } \\
\text { Bristow, \& Romero- } \\
\text { Sierra, 1977) }\end{array}$ \\
\hline $\begin{array}{l}\text { Effects of Microwave Energy on the Strophiole, Seed Coat and } \\
\text { Germination of Acacia Seeds }\end{array}$ & (Tran, 1979) \\
\hline $\begin{array}{l}\text { The effect of microwave-energy on germination and dormancy of wild } \\
\text { oat seeds }\end{array}$ & (Lal \& Reed, 1980) \\
\hline The Effect of Externally Applied Electrostatic Fields, Microwave & (Diprose, Benson, \& \\
\hline $\begin{array}{l}\text { Radiation and Electric Currents on Plants and Other Organisms, with } \\
\text { Special Reference to Weed Control }\end{array}$ & Willis, 1984) \\
\hline Control of field weeds by microwave radiation & (Vela-Múzquiz, 1984) \\
\hline $\begin{array}{l}\text { Effect of microwave irradiation on germination and initial growth of } \\
\text { mustard seeds }\end{array}$ & $\begin{array}{l}\text { (Rao, Chakravarthy, \& } \\
\text { Panda, 1989) }\end{array}$ \\
\hline Inhibition of weed seed germination by microwaves & (Barker \& Craker, 1991) \\
\hline $\begin{array}{l}\text { A possibility of correction of vital processes in plant cell with microwave } \\
\text { radiation }\end{array}$ & $\begin{array}{l}\text { (Petrov, Moiseeva, \& } \\
\text { Morozova, 1991) }\end{array}$ \\
\hline Microwave irradiation of seeds and selected fungal spores & $\begin{array}{l}\text { (Cavalcante \& Muchovej, } \\
\text { 1993) }\end{array}$ \\
\hline $\begin{array}{l}\text { Response surface models to describe the effects and phytotoxic } \\
\text { thresholds of microwave treatments on barley seed germination and } \\
\text { vigour }\end{array}$ & $\begin{array}{l}\text { (Stephenson, } \\
\text { Kushalappa, Raghavan, \& } \\
\text { Mather, 1996) }\end{array}$ \\
\hline Energy Efficient Soil Disinfestation by Microwaves & $\begin{array}{l}\text { (Mavrogianopoulos, } \\
\text { Frangoudakis, \& } \\
\text { Pandelakis, 2000) }\end{array}$ \\
\hline $\begin{array}{l}\text { Microwave effects on germination and growth of radish (Raphanus } \\
\text { sativus L.) seedlings }\end{array}$ & $\begin{array}{l}\text { (Scialabba \& Tamburello, } \\
\text { 2002) }\end{array}$ \\
\hline $\begin{array}{l}\text { Report on the Development of Microwave System for Sterilisation of } \\
\text { Weed Seeds: Stage I - Feasibility }\end{array}$ & $\begin{array}{l}\text { (Advanced Manufacturing } \\
\text { Technologies, 2003) }\end{array}$ \\
\hline $\begin{array}{l}\text { Design, construction and preliminary tests of a microwave prototype for } \\
\text { weed control }\end{array}$ & $\begin{array}{l}\text { (Zanche, Amista, Baldoin, } \\
\text { Beria, \& Giubbolini, } \\
\text { 2003) }\end{array}$ \\
\hline Thermal effects of microwave energy in agricultural soil radiation & $\begin{array}{l}\text { (Velazquez-Marti \& } \\
\text { Gracia-Lopez, 2004) }\end{array}$ \\
\hline $\begin{array}{l}\text { Influence of low-frequency and microwave electromagnetic fields on } \\
\text { seeds }\end{array}$ & $\begin{array}{l}\text { (Kalinin, Boshkova, } \\
\text { Panchenko, \& } \\
\text { Kolomiichuk, 2005) }\end{array}$ \\
\hline An improved microwave weed killer & (Vidmar, 2005) \\
\hline
\end{tabular}


Table 6.1: Literature addressing the application of microwave technology to seed and weed treatment.

\begin{tabular}{|c|c|}
\hline Paper Title & Reference \\
\hline Observations on the potential of microwaves for weed control & $\begin{array}{l}\text { (Sartorato, Zanin, } \\
\text { Baldoin, \& De Zanche, } \\
\text { 2006) }\end{array}$ \\
\hline Plant response to microwaves at $2.45 \mathrm{GHz}$. & (Skiles, 2006) \\
\hline $\begin{array}{l}\text { Germination Inhibition of Undesirable Seed in the Soil using Microwave } \\
\text { Radiation }\end{array}$ & $\begin{array}{l}\text { (Velazquez-Marti, } \\
\text { Gracia-Lopez, \& Marzal- } \\
\text { Domenech, 2006) }\end{array}$ \\
\hline $\begin{array}{l}\text { Effect of microwave radiation on seed mortality of rubber vine } \\
\text { (Cryptostegia grandiflora R.Br.), parthenium (Parthenium } \\
\text { hysterophorous L.) and bellyache bush (Jatropha gossypiifolia L.) }\end{array}$ & (Bebawi et al., 2007) \\
\hline $\begin{array}{l}\text { Effects of microwave treatment on growth, photosynthetic pigments } \\
\text { and some metabolites of wheat }\end{array}$ & (Hamada, 2007) \\
\hline $\begin{array}{l}\text { Microwave seed treatment reduces hardseededness in Stylosanthes } \\
\text { seabrana and promotes redistribution of cellular water as studied by } \\
\text { NMR relaxation measurements }\end{array}$ & $\begin{array}{l}\text { (Anand, S, Joshi, Verma, } \\
\text { \& Kar, 2008) }\end{array}$ \\
\hline $\begin{array}{l}\text { Effect of microwave fields on the germination period and shoot growth } \\
\text { rate of some seeds }\end{array}$ & $\begin{array}{l}\text { (Monteiro, Mendiratta, \& } \\
\text { Capitão, 2008) }\end{array}$ \\
\hline $\begin{array}{l}\text { Germination of Chenopodium Album in Response to Microwave Plasma } \\
\text { Treatment }\end{array}$ & $\begin{array}{l}\text { (Sera, Stranak, Sery, } \\
\text { Tichy, \& Spatenka, 2008) }\end{array}$ \\
\hline $\begin{array}{l}\text { Work conditions for microwave applicators designed to eliminate } \\
\text { undesired vegetation in a field }\end{array}$ & $\begin{array}{l}\text { (Velazquez-Marti, Gracia- } \\
\text { Lopez, \& de la Puerta, } \\
\text { 2008) }\end{array}$ \\
\hline
\end{tabular}

\subsection{Microwave Weed and Soil Treatment Patents}

The long-standing interest in applying microwave technology to weed and soil treatment has resulted in many attempts to capture the intellectual property through various patents (Tab. 6.2). It is evident that some of these are the same invention; however, they have been patented in different parts of the world. Patents have included two main methods of soil treatment: in-situ treatment systems that do not disturb the soil (Clark \& Kissell, 2003; Haller, 2002; Joines, 2009); and tunnel treatment systems which use some mechanical method to remove the top soil, pass it through a microwave treatment chamber or tunnel and then return the soil to its original position after treatment (Wall, 2009). The in-situ treatment systems use various antenna systems or multi-mode cavities (somewhat like half of a microwave oven that is open to the soil) to apply the microwave energy (For example: Clark \& Kissell, 2003; Haller, 2002). Several of these patents claim to control other crop pests as well as weeds and their seeds in the soil (Grigorov, 2003; Haller, 2002; Joines, 2009). There are also several companies that have developed microwave based weed management technologies, but have chosen not to apply for a patent to protect their inventions. There will be others that the authors are not aware of. Some of these 
companies have developed mature technologies; however most have systems that are in the developmental stage.

\subsection{Conclusion}

It is clear from the number of papers, patents and other evidence that the basic principle of microwave weed management is of considerable interest and is well understood. Several system designs have been developed and protected; however, there is still scope to develop novel microwave applicator designs that better couple the microwave energy into the soil and weed plants. There is also opportunity to develop and implement better energy control systems that could reduce the energy required to achieve effective soil and weed treatment and automate the weed management process.

On the more cautionary side, in a theoretical argument based on the dielectric and physical properties of seeds and soils, Nelson (1996) demonstrated that using microwaves to selectively heat seeds in the soil "cannot be expected." He stated that seed susceptibility to damage from microwave treatment is a purely thermal effect, resulting from soil heating and thermal conduction into the seeds. He concluded that microwave weed management was not viable; however, his arguments ignored any effects of herbicide resistance on crop yields.

Table 6.2: Patents which address or are associated with microwave weed and soil treatment.

\begin{tabular}{|c|c|c|c|c|}
\hline Publication Number & Priority Date & Filing Date & $\begin{array}{l}\text { Date of } \\
\text { Publication }\end{array}$ & Title \\
\hline EP 0413847 A1 & $17 / 10 / 1986$ & $24 / 08 / 1989$ & 27/02/1991 & \multirow{4}{*}{$\begin{array}{l}\text { Microwave/steam sterilizer. } \\
\text { | Mikrowellen-/Dampf- } \\
\text { Sterilisator. | Stérilisateur à } \\
\text { micro-ondes et à vapeur. } \\
\text { Method for killing soil } \\
\text { pathogens with micro-wave } \\
\text { energy }\end{array}$} \\
\hline US4861956A & & $17 / 10 / 1986$ & 29/08/1989 & \\
\hline W01991002548A1 & & 24/08/1989 & 7/03/1991 & \\
\hline US5287818A & $11 / 05 / 1993$ & $11 / 05 / 1993$ & $22 / 02 / 1994$ & \\
\hline US5141059A & 27/02/1991 & 27/02/1991 & 25/08/1992 & $\begin{array}{l}\text { Method and apparatus for } \\
\text { controlling agricultural pests } \\
\text { in soil }\end{array}$ \\
\hline CA2299301 A1 & $16 / 08 / 1996$ & $15 / 08 / 1996$ & $26 / 02 / 1998$ & \multirow{7}{*}{$\begin{array}{l}\text { Method and device for } \\
\text { weed control | Procede et } \\
\text { dispositif de desherbage | } \\
\text { Verfahren und vorrichtung zur } \\
\text { unkrautbekämpfung }\end{array}$} \\
\hline DE69625089D1 & & $16 / 08 / 1996$ & $9 / 01 / 2003$ & \\
\hline DE69625089T2 & & $16 / 08 / 1996$ & $4 / 09 / 2003$ & \\
\hline EP0928134 A1 & & $16 / 08 / 1996$ & 14/07/1999 & \\
\hline EP0928134 B1 & & $16 / 08 / 1996$ & $27 / 11 / 2002$ & \\
\hline US6237278B1 & & $16 / 08 / 1996$ & $29 / 05 / 2001$ & \\
\hline W01998/007314 A1 & $20 / 02 / 1995$ & $16 / 08 / 1996$ & $26 / 02 / 1998$ & \\
\hline
\end{tabular}


Continued Table 6.2: Patents which address or are associated with microwave weed and soil treatment.

\begin{tabular}{|c|c|c|c|c|}
\hline Publication Number & Priority Date & Filing Date & $\begin{array}{l}\text { Date of } \\
\text { Publication }\end{array}$ & Title \\
\hline $\begin{array}{l}\text { DE } 19850195 \text { A1 } \\
\text { DE } 59915075 \text { D1 } \\
\text { EP } 1158853 \text { A1 } \\
\text { W02000/024247 A1 }\end{array}$ & $22 / 10 / 1998$ & $\begin{array}{l}22 / 10 / 1999 \\
22 / 10 / 1999 \\
22 / 10 / 1999 \\
22 / 10 / 1999\end{array}$ & $\begin{array}{l}4 / 05 / 2000 \\
1 / 02 / 2007 \\
5 / 12 / 2001 \\
4 / 05 / 2000\end{array}$ & $\begin{array}{l}\text { Method and device for killing } \\
\text { wood-destroying animals | } \\
\text { Procede et dispositif pour } \\
\text { exterminer des parasites } \\
\text { animaux dans le bois | } \\
\text { Verfahren und vorrichtung } \\
\text { zum abtöten von tierischen } \\
\text { schädlingen in holz }\end{array}$ \\
\hline $\begin{array}{l}\text { CA2372471A1 } \\
\text { CA2372471C } \\
\text { DE60114392D1 } \\
\text { DE60114392T2 } \\
\text { EP1272032A1 } \\
\text { EP1272032B1 } \\
\text { US20030037582A1 } \\
\text { US6647661B2 } \\
\text { W02001/076362 A1 }\end{array}$ & $4 / 04 / 2000$ & $\begin{array}{l}3 / 04 / 2001 \\
3 / 04 / 2001 \\
3 / 04 / 2001 \\
3 / 04 / 2001 \\
3 / 04 / 2001 \\
3 / 04 / 2001 \\
3 / 04 / 2001 \\
3 / 04 / 2001 \\
3 / 04 / 2001\end{array}$ & $\begin{array}{l}18 / 10 / 2001 \\
11 / 12 / 2007 \\
1 / 12 / 2005 \\
27 / 07 / 2006 \\
8 / 01 / 2003 \\
26 / 10 / 2005 \\
27 / 02 / 2003 \\
18 / 11 / 2003 \\
18 / 10 / 2001\end{array}$ & $\begin{array}{l}\text { Method and system for } \\
\text { exterminating pests, weeds } \\
\text { and pathogens | Procede } \\
\text { et systeme d'extermination } \\
\text { d'animaux nuisibles, de } \\
\text { plantes nuisibles et d'agents } \\
\text { pathogenes | Verfahren und } \\
\text { system zur vernichtung von } \\
\text { ungeziefer, unkraut und } \\
\text { pathogenen }\end{array}$ \\
\hline $\begin{array}{l}\text { US } 6401637 \text { B1 } \\
\text { US } 20020090268\end{array}$ & $8 / 01 / 2001$ & $\begin{array}{l}15 / 06 / 2001 \\
15 / 06 / 2001\end{array}$ & $\begin{array}{l}11 / 06 / 2002 \\
11 / 07 / 2002\end{array}$ & Microwave energy applicator \\
\hline $\begin{array}{l}\text { EP } 1224863 \text { A2 } \\
\text { EP } 1224863 \text { A3 } \\
\text { US20040009092A1 }\end{array}$ & $15 / 11 / 2001$ & $\begin{array}{l}15 / 11 / 2001 \\
15 / 11 / 2001 \\
15 / 07 / 2002\end{array}$ & $\begin{array}{l}24 / 07 / 2002 \\
21 / 09 / 2005 \\
15 / 01 / 2004\end{array}$ & $\begin{array}{l}\text { Microwave disinfestation } \\
\text { system for biological pests } \\
\text { | Système de désinfection } \\
\text { à micro-ondes pour lutte } \\
\text { biologique | Mikrowellendes } \\
\text { Infektionsystem } \\
\text { für biologische } \\
\text { Schädlinsgbekämpfung }\end{array}$ \\
\hline $\begin{array}{l}\text { CA } 2483749 \text { A1 } \\
\text { CN } 1642414 \text { A } \\
\text { DE } 10213983 \text { C1 } \\
\text { EP } 1487263 \text { A1 } \\
\text { US 20050039379 A1 } \\
\text { W02003/081999 A1 }\end{array}$ & $28 / 03 / 2002$ & $\begin{array}{l}27 / 03 / 2003 \\
27 / 03 / 2003 \\
28 / 03 / 2002 \\
27 / 03 / 2003 \\
27 / 09 / 2004 \\
27 / 03 / 2003\end{array}$ & $\begin{array}{l}9 / 10 / 2003 \\
20 / 07 / 2005 \\
13 / 11 / 2003 \\
22 / 12 / 2004 \\
24 / 02 / 2005 \\
9 / 10 / 2003\end{array}$ & $\begin{array}{l}\text { Method and apparatus } \\
\text { [device] for controlling } \\
\text { pests found in the ground, } \\
\text { in particular termites | } \\
\text { Procede et dispositif pour } \\
\text { lutter contre les animaux } \\
\text { nuisibles vivant dans le sol, } \\
\text { en particulier les termites | } \\
\text { Verfahren und Vorrichtung } \\
\text { zur Bekämpfung von im } \\
\text { Erdboden hausenden } \\
\text { Schädlingen, insbesondere } \\
\text { Termiten |防治在土壤中筑巢 } \\
\text { 的有害动物特别是白蚁的方 } \\
\text { 法和装置 }\end{array}$ \\
\hline
\end{tabular}


Table 6.2: Patents which address or are associated with microwave weed and soil treatment.

\begin{tabular}{|c|c|c|c|c|}
\hline Publication Number & Priority Date & Filing Date & $\begin{array}{l}\text { Date of } \\
\text { Publication }\end{array}$ & Title \\
\hline US20030215354 A1 & $17 / 05 / 2002$ & $16 / 09 / 2002$ & $20 / 11 / 2003$ & \multirow{3}{*}{$\begin{array}{l}\text { Systems and methods for } \\
\text { in situ soil sterilization, } \\
\text { insect extermination and } \\
\text { weed killing | Systemes et } \\
\text { procedes de sterilisation des } \\
\text { sols in situ, d'extermination } \\
\text { des insectes et de } \\
\text { desherbage }\end{array}$} \\
\hline $\begin{array}{l}\text { W02003/099004 } \\
\text { A2 }\end{array}$ & & $4 / 10 / 2002$ & $4 / 12 / 2003$ & \\
\hline $\begin{array}{l}\text { W02003/099004 } \\
\text { A3 }\end{array}$ & & $4 / 10 / 2002$ & $17 / 06 / 2004$ & \\
\hline US20060186115A1 & $11 / 01 / 2005$ & $11 / 01 / 2006$ & $24 / 08 / 2006$ & \multirow{4}{*}{$\begin{array}{l}\text { Microwave system and } \\
\text { method for controlling the } \\
\text { sterlization and infestation } \\
\text { of crop soils }\end{array}$} \\
\hline US20090232602A1 & & $22 / 09 / 2009$ & $17 / 09 / 2009$ & \\
\hline US7601936B2 & & & 13/10/2009 & \\
\hline US201220091123A1 & & & $19 / 04 / 2012$ & \\
\hline US20080149625A1 & \multirow[t]{4}{*}{$25 / 10 / 2006$} & $25 / 10 / 2006$ & $26 / 06 / 2008$ & \multirow{2}{*}{$\begin{array}{l}\text { Device for soil sterilization, } \\
\text { insect extermination, } \\
\text { and weed killing using } \\
\text { microwave energy }\end{array}$} \\
\hline US7560673B2 & & $25 / 10 / 2006$ & $14 / 07 / 2009$ & \\
\hline W02008057215A2 & & $24 / 10 / 2007$ & $15 / 05 / 2008$ & \multirow{2}{*}{$\begin{array}{l}\text { A device and method for } \\
\text { soil sterilization, insect } \\
\text { extermination, and weed } \\
\text { killing using microwave } \\
\text { energy / Dispositif et procédé } \\
\text { de stérilisation de sol, } \\
\text { d'extermination d'insectes et } \\
\text { de désherbage par énergie } \\
\text { micro-onde }\end{array}$} \\
\hline W02008057215A3 & & $24 / 10 / 2007$ & $24 / 07 / 2008$ & \\
\hline US 20130212928 A1 & $17 / 02 / 2012$ & $13 / 02 / 2013$ & $22 / 08 / 2013$ & \multirow{4}{*}{$\begin{array}{l}\text { Apparatus for using } \\
\text { microwave energy for } \\
\text { insect and pest control and } \\
\text { methods thereof | Appareil } \\
\text { d'utilisation de l'énergie } \\
\text { micro-onde pour le contrôle } \\
\text { des insectes et des animaux } \\
\text { nuisibles et procédés } \\
\text { associés }\end{array}$} \\
\hline US 20150101239A1 & & $18 / 12 / 2014$ & $16 / 04 / 2015$ & \\
\hline US 8943744 B2 & & $13 / 02 / 2013$ & $3 / 02 / 2015$ & \\
\hline W02013/123089 A1 & & $13 / 02 / 2013$ & $22 / 08 / 2013$ & \\
\hline
\end{tabular}

\subsection{References}

Advanced Manufacturing Technologies. (2003). Report on the Development of Microwave System for Sterilisation of Weed Seeds: Stage I - Feasibility. Retrieved from Wollongong, NSW.

Anand, A., S, N., Joshi, D. K., Verma, A. P.-S., \& Kar, A. (2008). Microwave seed treatment reduces hardseededness in Stylosanthes seabrana and promotes redistribution of cellular water as studied by NMR relaxation measurements. Seed Science and Technology, 37(1), 88-97.

Anonymous. (1975). Prize Winning Products from the IR-100 Show. Popular Science, January, 46. 
Ark, P. A., \& Parry, W. (1940). Application of High-Frequency Electrostatic Fields in Agriculture. The Quarterly Review of Biology, 15(2), 172-191.

Barker, A. V., \& Craker, L. E. (1991). Inhibition of weed seed germination by microwaves. Agronomy Journal, 83(2), 302-305.

Bebawi, F. F., Cooper, A. P., Brodie, G. I., Madigan, B. A., Vitelli, J. S., Worsley, K. J., \& Davis, K. M. (2007). Effect of microwave radiation on seed mortality of rubber vine (Cryptostegia grandiflora R.Br.), parthenium (Parthenium hysterophorous L.) and bellyache bush (Jatropha gossypiifolia L.). Plant Protection Quarterly, 22(4), 136-142.

Bigu-Del-Blanco, J., Bristow, J. M., \& Romero-Sierra, C. (1977). Effects of low-level microwave radiation on germination and growth rate in corn seeds. Proceedings of the IEEE, 65(7), 10861088.

Brodie, G., Harris, G., Pasma, L., Travers, A., Leyson, D., Lancaster, C., \& Woodworth, J. (2009). Microwave soil heating for controlling ryegrass seed germination. Transactions of the American Society of Agricultural and Biological Engineers, 52(1), 295-302.

Cavalcante, M. J. B., \& Muchovej, J. J. (1993). Microwave irradiation of seeds and selected fungal spores. Seed Science and Technology, 21(1), 247-253.

Clark, W. J., \& Kissell, C. W. (2003). United States Patent No. 20030215354 A1.

Davis, F. (1974). New techniques in weed control via microwaves. Paper presented at the Western Session- Southeastern Nurserymen's Conferences Nacogdoches, Texas.

Davis, F. S., Wayland, J. R., \& Merkle, M. G. (1971). Ultrahigh-Frequency Electromagnetic Fields for Weed Control: Phytotoxicity and Selectivity. Science, 173(3996), 535-537.

Davis, F. S., Wayland, J. R. and Merkle, M. G. (1973). Phytotoxicity of a UHF Electromagnetic Field. Nature, 241(5387), 291-292.

Diprose, M. F., Benson, F. A., \& Willis, A. J. (1984). The Effect of Externally Applied Electrostatic Fields, Microwave Radiation and Electric Currents on Plants and Other Organisms, with Special Reference to Weed Control. Botanical Review, 50(2), 171-223.

Grigorov, G. R. (2003). United States Patent No. $20030037482 \mathrm{A1}$.

Haller, H. E. (2002). United States Patent No. 20020090268 A1.

Hamada, E. (2007). Effects of microwave treatment on growth, photosynthetic pigments and some metabolites of wheat. Biologia Plantarum, 51(2), 343-345.

Joines, W. T. (2009). United States Patent No. US7601936B2.

Jolly, J. A., \& Tate, R. L. (1971). Douglas- fir tree seed germination enhancement using microwave energy. Journal of Microwave Power, 6(2), 125-130.

Kalinin, L. G., Boshkova, I. L., Panchenko, G. I., \& Kolomiichuk, S. G. (2005). Influence of lowfrequency and microwave electromagnetic fields on seeds. Biophysics, 50(2), 334-337.

Kashyap, S. C., \& Lewis, J. E. (1974). Microwave processing of tree seeds. Journal of Microwave Power, 9(2), 99-107.

Lal, R., \& Reed, W. B. (1980). The effect of microwave-energy on germination and dormancy of wild oat seeds. Canadian Agricultural Engineering, 22(1), 85-88.

Mavrogianopoulos, G. N., Frangoudakis, A., \& Pandelakis, J. (2000). Energy Efficient Soil Disinfestation by Microwaves. Journal of Agricultural Engineering Research, 75(2), 149-153

Menges, R. M., \& Wayland, J. R. (1974). UHF electromagnetic energy for weed control in vegetables. Weed Science, 22(6), 584-590.

Monteiro, J. H., Mendiratta, S. K., \& Capitão, A. (2008). Effect of microwave fields on the germination period and shoot growth rate of some seeds. Paper presented at the International Conference of Recent Advances in Microwave Theory and Applications, Jaipur, Rajasthan.

Nelson, S. O. (1996). A review and assessment of microwave energy for soil treatment to control pests. Transactions of the ASAE, 39(1), 281-289.

Nelson, S. O., Ballard, L. A. T., Stetson, L. E., \& Buchwald, T. (1976). Increasing legume seedgermination by VHF and microwave dielectric heating. Transactions of the ASAE, 19(2), 369-371. 
Nelson, S. O., \& Stetson, L. E. (1985). Germination responses of selected plant species to RF electrical seed treatment. Transactions of the ASAE, 28(6), 2051-2058.

Petrov, I. Y., Moiseeva, T. V., \& Morozova, E. V. (1991). A possibility of correction of vital processes in plant cell with microwave radiation. Paper presented at the 1991 IEEE International Symposium on Electromagnetic Compatibility, Cherry Hill, NJ, USA.

Rao, Y. V. S., Chakravarthy, N. V. K., \& Panda, B. C. (1989). Effect of microwave irradiation on germination and initial growth of mustard seeds. Indian Journal of Agronomy, 34(3), 378-379.

Sartorato, I., Zanin, G., Baldoin, C., \& De Zanche, C. (2006). Observations on the potential of microwaves for weed control. Weed Research, 46(1), 1-9.

Scialabba, A., \& Tamburello, C. (2002). Microwave effects on germination and growth of radish (Raphanus sativus L.) seedlings. Acta Botanica Gallica, 149(2), 113-123.

Sera, B., Stranak, V., Sery, M., Tichy, M., \& Spatenka, P. (2008). Germination of Chenopodium Album in Response to Microwave Plasma Treatment. Plasma Science and Technology, 10(4), 506-511.

Skiles, J. W. (2006). Plant response to microwaves at $2.45 \mathrm{GHz}$. Acta Astronautica, 58(5), 258-263. doi:DOI: 10.1016/j.actaastro.2005.12.007

Stephenson, M. M. P., Kushalappa, A. C., Raghavan, G. S. V., \& Mather, D. E. (1996). Response surface models to describe the effects and phytotoxic thresholds of microwave treatments on barley seed germination and vigour. Seed Science and Technology, 24(1), 49-65.

Tran, V. N. (1979). Effects of Microwave Energy on the Strophiole, Seed Coat and Germination of Acacia Seeds. Australian Journal of Plant Physiology, 6(3), 277-287.

Vela-Múzquiz, R. (1984). Control of field weeds by microwave radiation. Paper presented at the II International Symposium on Soil Disinfestation.

Velazquez-Marti, B., \& Gracia-Lopez, C. (2004). Thermal effects of microwave energy in agricultural soil radiation. International Journal of Infrared and Millimeter Waves, 25(7), 1109-1122.

Velazquez-Marti, B., Gracia-Lopez, C., \& de la Puerta, R. (2008). Work conditions for microwave applicators designed to eliminate undesired vegetation in a field. Biosystems Engineering, 100(1), 31-37.

Velazquez-Marti, B., Gracia-Lopez, C., \& Marzal-Domenech, A. (2006). Germination Inhibition of Undesirable Seed in the Soil using Microwave Radiation. Biosystems Engineering, 93(4), 365373.

Vidmar, M. (2005). An improved microwave weed killer. Microwave Journal, 48(10), 116-126.

Wall, G. W. (2009). United States Patent No. US7560673B2.

Wayland, J., Merkle, M., Davis, F., Menges, R. M., \& Robinson, R. (1975). Control of weeds with UHF electromagnetic fields. Unkrautbekämpfung mit elektromagnetischen UHF-Feldern., 15(1), 1-5.

Zanche, C. d., Amista, F., Baldoin, C., Beria, S., \& Giubbolini, L. (2003). Design, construction and preliminary tests of a microwave prototype for weed control. Rivista di Ingegneria Agraria, 34(2), 31-38. 